\title{
Who's to Act? Perceptions of Intergenerational Obligation and Pro-Environmental Behaviours among Youth
}

\author{
Oriane Sarrasin ${ }^{1, * \mathbb{D}}$, Fabienne Crettaz von Roten $^{2}$ and Fabrizio Butera ${ }^{1}$ (ID \\ 1 Institute of Psychology, Faculty of Social and Political Sciences, University of Lausanne, 1015 Lausanne, \\ Switzerland; fabrizio.butera@unil.ch \\ 2 Institute of Sport Sciences, Faculty of Social and Political Sciences, University of Lausanne, 1015 Lausanne, \\ Switzerland; Fabienne.crettazvonroten@unil.ch \\ * Correspondence: oriane.sarrasin@unil.ch
}

Citation: Sarrasin, O.; Crettaz von Roten, F.; Butera, F. Who's to Act? Perceptions of Intergenerational Obligation and Pro-Environmental Behaviours among Youth. Sustainability 2022, 14, 1414. https:/ / doi.org/10.3390/su14031414

Academic Editor: Ricardo García Mira

Received: 8 December 2021

Accepted: 21 January 2022

Published: 26 January 2022

Publisher's Note: MDPI stays neutral with regard to jurisdictional claims in published maps and institutional affiliations.

Copyright: (C) 2022 by the authors. Licensee MDPI, Basel, Switzerland. This article is an open access article distributed under the terms and conditions of the Creative Commons Attribution (CC BY) license (https:// creativecommons.org/licenses/by/ $4.0 /)$.

\begin{abstract}
We are all in the same boat" are words heard from young climate activists, suggesting that all generations must engage together in the fight against climate change. However, because of their age and life situation, some young people may feel unable to change the situation and attribute the moral obligation to do so to older generations. Whether such attributions restrict young people from engaging in pro-environmental behaviours remains largely unstudied. To fill this gap, the present study incorporated perceptions of self-efficacy, feelings of external control, and intergenerational obligation (i.e., believing that all generations should act) into the Value-Belief-Norm model. Data from high school $(n=639)$ and bachelor $(n=1509)$ students in French-speaking Switzerland showed that perceptions of self-efficacy and intergenerational obligation predicted the probability of engaging in both an actual behaviour (Study 1) and a costly educational commitment (Study 2), while perceiving that the fate of the Earth lies in the hands of powerful others did not. These results suggest that educational programs on climate change should integrate intergenerational components.
\end{abstract}

Keywords: youth; pro-environmental behaviours; external control; intergenerational obligation; value-belief-norm model

\section{Introduction}

The future of today's youth may appear rather grim. According to the 2021 report of the Intergovernmental Panel on Climate Change [1], humans have only a few years left to take more serious action to limit global warming under $1.5^{\circ} \mathrm{C}$; anything higher will have disastrous consequences for both nature and humankind. Thus, to achieve this goal, younger generations are left with a much lower "carbon budget" than their parents and grandparents. The last few years have witnessed young people increasingly worried about climate change [2,3]. In 2018 and 2019 (mostly, as the COVID-19 pandemic did not then allow broad assemblies), thousands, if not millions, of young people took the street to protest every Friday for a greener planet [4]. Young people of today are "most vulnerable to the legacy of decisions made by the older generations" [5] (p. 523). They may thus see all generations as jointly accountable and responsible to fight against climate change. Others may think, however, that the moral obligation to act for the environment lies primarily with one generation; either the previous generation(s), because they contributed far more to current and future environmental issues, or their own, because it will face the increasingly worrying consequences of climate change.

Research has yet to investigate to what extent young people feel (un)able to act for the environment and to whom they attribute the moral obligation to do so and, importantly, how these perceptions affect their pro-environmental behaviours. Indeed, if found to be relevant, the notions of control and of either generational or intergenerational obligation should be integrated in educational programmes on climate change. To fill this gap, the present research inquired across two studies whether youth in French-speaking 
Switzerland viewed their own generations and older ones as jointly responsible to act for the environment, or not. Then, we examined to what extent such a representation of intergenerational vs. generational obligation-a variable that has, to our knowledge, not been investigated yet-underlaid young people's propensity to engage in actual proenvironmental behaviours (Study 1) and in a costly educational commitment (Study 2). To this end, we incorporated the notions of external control and intergenerational vs. generational obligation into the predictive model of Value-Belief-Norm (VBN) theory [6,7].

\subsection{The Value-Belief-Norm (VBN) Theory}

Uniting major strands of research on pro-environmental attitudes and behaviours (e.g., value theory; [8,9]; the New Environmental Paradigm [10]), the Value-Belief-Norm theory [6,7] assumes that an individual's values stand at the beginning of a chain that explains an individual's propensity to engage in pro-environmental behaviours. General and stable elements of an individual's personality, personal values trigger more focused (that is, directly related to the environment) beliefs (e.g., awareness of adverse consequences for the environment, perceived ability to act upon them). These beliefs generate, in turn, a "sense of obligation to take pro-environmental actions" [6] (p. 412), labelled personal norms. Finally, norms are the very factor that underlies pro-environmental behaviours.

As detailed hereafter, the VBN concepts were here adapted to account for the particular situation in life of young people still in education. Indeed, high school and bachelor students - the target samples in the present research-may not see themselves as able to act for the environment [11,12]. For this reason and going beyond the usual ways of measuring an individual's perceived personal ability to reduce environmental threat, we included several measures of perceived control, involving environment and nature seen as either in the hands of the participants themselves or of external forces. The notion of norms, traditionally defined as the personal moral obligation to act for the environment, was also extended to encompass other generations. In this respect, the present research extends the application of VBN theory to more collective elements, a much-needed direction in human and social sciences investigating the antecedents of pro-environmental behaviours $[13,14]$. Indeed, "actions that could be taken to mitigate climate change are costly to individuals, while significant benefits are only reaped if sufficiently large numbers of individuals choose to reduce their emissions" [15] (p. 195).

\subsubsection{Biospheric, Altruistic and Egoistic Values}

Values are the first step of the VBM chain. Defined as "the central cultural and individual goals that people hold and aspire to achieve" [16] (p.185), basic personal values are assumed in the VBN theory to act as a rather stable frame that guides the extent to which individuals pay attention to environment-related issues. Research has shown that, in particular, three sets of values matter in the formation of pro-environmental attitudes and behaviours (e.g., [6,17,18]), namely biospheric, altruistic, and egoistic values. These values are to be found on the self-transcendence (the priority is given to others, including nonhuman others, such as the natural environment) vs. self-enhancement (the priority is given to self-interest) axis of the value circumplex theorised by Schwartz and his colleagues [9].

Biospheric (caring for nature, also called universalism-nature [19]) and altruistic values (caring for other people, also called universalism-concern, benevolence-caring and benevolence-dependability [19]) entail transcending one's own interest. While the VBN theory proposed that both types should predict pro-environmental behaviours, empirical studies have shown that biospheric values have a much stronger impact (directly, or through beliefs and norms as postulated by the VBN theory), while altruistic values have a weaker (e.g., [20,21]) or even non-significant (e.g., [22]) effect. This may be partly due to biospheric values underlying a general pro-environmental outlook, while altruistic values predict specific forms of environment-related beliefs. For instance, benevolence (the priority given to caring for friends and relatives) was found to relate to a stronger awareness of environmental issues for close others (e.g., the effect of pollution on public 
health), but not for the nature in general [23]. In contrast to biospheric and altruistic values, egoistic values (e.g., achievement and power, [19]) involve prioritizing one's own interest. Since adopting pro-environmental behaviours often implies renouncing personal pleasures, interests, or commodities to act for the common good [24], unsurprisingly egoistic values have repeatedly been found to predict (directly or indirectly) a lower willingness to engage into pro-environmental behaviours (e.g., $[20,21,25])$.

Although personal values are conceptualized as rather stable traits, changes may be observed across an individual's life course [26], and particularly during adolescence and young adulthood (e.g., in tradition, [27]; in achievement, [28-30]). Does the importance granted to self-transcendence values change during these critical years, and if so, does it impact young people's willingness to act for the environment? In Italy, Vecchione and colleagues [30] showed an increase in self-transcendence values during an individual's twenties, while a study conducted among Swedish high schoolers found no change in the average importance granted to biospheric values in earlier years (from 17 to 18; [31]). However, whether or not the importance granted to biospheric values evolves over time, these values were repeatedly found to underlie ecological beliefs [32], a higher willingness to engage in pro-environmental behaviours [31], and private-sphere pro-environmental behaviours [33] among young people.

\subsubsection{Beliefs}

According to VBN theory, personal values explain the amount of attention that individuals devote to environmental issues, through a chain of three sets of beliefs. First, values have a direct impact on individuals' general ecological worldviews, or, in other words, how people perceive the relations between humans and nature. Second, broad and general ecological worldviews are assumed to increase individual awareness of general (e.g., "global warming is a problem for society" [34]), or specific (e.g., "car use causes exhaustion of scarce resources, such as oil" [17]) consequences of climate change (awareness of consequences or $\mathrm{AC}$ ). Regarding awareness, one important question is the extent to which young people of today are aware of the consequences of climate change. Studies a decade old or more revealed, in Western countries, a "dip" in interest for sustainable development between around 13 and 17 years old (for a review, see [35]). In addition, US high schoolers born in the 1980s and 1990s were found to express a much lower interest in the environment than high schoolers from the previous generation [36]. However, from 2018, millions of young people took the streets to express their worry about climate change. Reviewing 51 studies conducted with children and adolescents (aged 8-19), Lee and colleagues [4] observed no marked changes in climate change perceptions in recent years but noted that studies on the topic published prior to 2007 were scarce. The authors also noticed marked cross-national differences in terms of child and adolescent levels of beliefs and concerns. By way of contrast, in an Australian longitudinal study on participants aged 10-11 to 18-19, most participants were found to express a stable or increasing worry for the environment [3]. Thus, it is important to ascertain the extent to which young people of today, and especially those with marked biospheric values, are aware of environmental issues and how those beliefs impact their willingness to act for the environment.

The third and last belief included in VBN theory relates to individuals' perceived ability to alleviate what is perceived to threaten the environment. Closely related to the extent to which individuals believe they have control over events [37], ascription of responsibility (AR) refers to the extent to which individuals feel personally responsible to act for the environment. Among young people, however, being aware of the adverse consequences of climate change may not fully translate into a heightened sense of control. Indeed, "children and adolescents experience lower levels of perceived and actual control over their individual and collective actions than adults, which can make younger audiences particularly likely to experience despair in the face of climate change" [12] (p. 1). Already in the late 1990s, Ballantyne and colleagues [38] also pointed to "a sense of powerlessness" among young adults (p. 286). For instance, feeling helpless regarding climate change 
was related to a lower perceived control over acting for the environment (in a distant and developing country) among German adolescents [39]. This may explain why young people are generally found to ascribe the responsibility to act to the government to a greater extent than to themselves, while at the same time supporting individualistic solutions to climate change to a greater extent (for a discussion on the topic, see [40]). Research conducted with young participants should thus go beyond measures of perceived own ability and include perceptions of the role played by external forces. For this reason, we introduced an important addition to the usual VBN-inspired items, that is a measure of both internal and external locus of control, in particular control exerted by powerful others, such as politicians and large companies.

\subsubsection{From Personal to Collective Obligation}

According to VBN theory, when individuals perceive a threat to the environment (i.e., they are aware of the consequences of climate change) and think that they have the ability to act upon it, they feel morally obliged to engage in pro-environmental behaviours (for a metaanalysis, see [41]). Personal norms are defined as a sense of moral obligation, which creates a predisposition to act. According to Stern and colleagues [7], personal norms underlie a wide range of pro-environmental behaviours: activism, nonactivist public-sphere behaviours, private-sphere behaviours, and behaviours in organization. VBN-inspired studies carried out with young participants generally included only measures of how individuals feel that they ought to act to limit climate change (or engage in specific pro-environmental behaviours). For instance, Kim and Shin [42], in a study conducted among college students in the US and South Korea, measured what they called perceived individual responsibility (e.g., measured through the agreement with statements such as "preventing global climate change starts with $\mathrm{me}^{\prime \prime}$ ). Menzel and Bögeholz [33], in a study conducted in Germany and Chile, used feelings of personal guilt to measure personal norms.

However, the strong interconnectedness between generations when it comes to climate change calls for considering a collective sense of moral obligation. Indeed, young people of today have contributed far less to climate change than previous generations and will have to rely on fewer resources if they want to maintain acceptable conditions on Earth. This is likely to affect their perceptions as to who should be in charge of acting to limit climate change. The moral obligation should thus be extended from themselves to older generations. On the one hand, young people may hold "we are all in the same boat"-type beliefs and perceive intergenerational cooperation as a necessary step to tackle environmental issues (positive interdependence). In this sense, limiting climate change would act as a superordinate goal that transcends group differences and rivalries [43]. Feelings of collective bonds when environmental issues are at stake are known to underlie individuals' pro-environmental behaviours [14]. On the other hand, adolescents may hold "us vs. them" beliefs and think that one generation is responsible to act to limit climate change (negative interdependence). They may attribute the responsibility to act for the environment either to previous generations, because of their greater contribution to climate change, or to their own generation, both because they will face the increasingly worsening consequences of climate change and because they feel they have the resources (e.g., motivation) to do so.

\subsection{The Present Theoretical Model}

Based on previous research, biospheric values are expected to positively relate to an ecological worldview, which, in turn, should relate to a greater awareness of the adverse consequences (AC) of climate change (see Figure 1). Then, the later stages of the VBN model are adapted to account for the peculiarities of young peoples' situations in life. First, we consider, in addition to individuals' ascriptions of responsibility (AR), their perceptions of the environment as in the hands of external forces. Whether AC translates into a higher AR (to oneself or to others) among youth is indeed an empirical question. On the one hand, because of their situation in life, as found with adult samples, young people aware of environmental issues (i.e., high in AC) may believe they have control over the actions 
to be carried out to limit climate change. On the other hand, AC may relate to a higher attribution of environmental issues to powerful others.

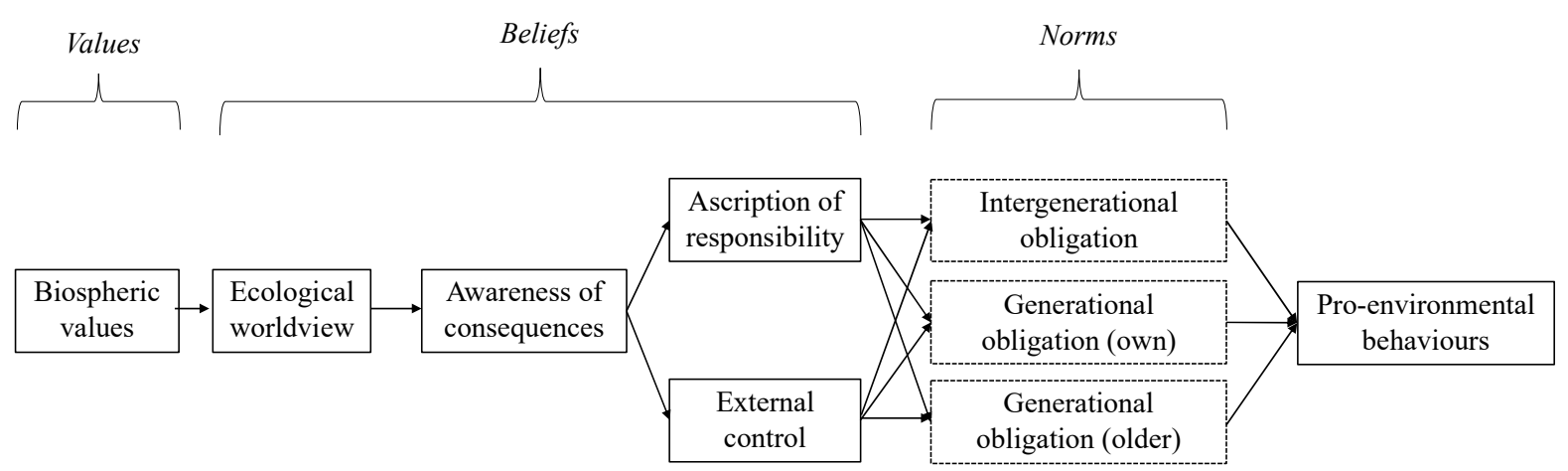

Figure 1. Theoretical model.

Norms, as predicted by the VBN model, should stem from a higher sense of control. However, because of young peoples' situation in life, it is crucial to go beyond one's personal sense of obligation. For this reason, we introduced a second important addition to the usual VBN-inspired items, i.e., the moral obligation to act for the environment that young people attribute to their own generation, and to older generations. Three scenarios are possible. In the intergenerational obligation scenario, young people see generations as positively interdependent: all generations must join their efforts to fight climate change. In the other two "generational obligation" scenarios the levels of responsibility young people attribute to their own generation vs. to older generations are distinct and negatively correlated. They may attribute the obligation to act only, or more strongly, either to their generation or to previous generations.

Due to the novelty of these measures, the exact links that tie AR, perceptions of intergenerational vs. generational moral obligation and pro-environmental behaviours are an empirical question. The role played by perceptions of intergenerational obligation remains open. It may be argued that since collective bonds underlie cooperative behaviours [44], feeling that all generations are jointly responsible may be related to behaviours that will benefit all humankind [45]. However, it is also possible that perceptions of one's own generation as responsible may arise from high levels of personal AR, and lead to stronger pro-environmental behaviours, whereas attributing the responsibility to act to older generations may stem from perceptions of external control and relate to a lower behavioural engagement. All these links will be explored in a first study, and a second study will be conducted to examine whether results are confirmed.

\section{Study 1}

\subsection{Method}

\subsubsection{Procedure and Participants}

Data were collected in September 2016 during a "sustainability day" organized by a high school in French-speaking Switzerland. Permission from an ethical committee was not requested (it was not necessary given extant regulations for the social sciences in Switzerland), but the study was approved by the school headmaster and the teachers involved in the event. Moreover, all parents were informed that their children (in case the latter were underage) would be invited to participate in a study. No parents refused.

In the morning, all students and teachers watched an environment-related documentary film and attended a public conference on environmental issues. In the afternoon, teachers administered the questionnaire, which bore both the university and the school logo. The day went on with workshops on environment-related activities. Altogether, 640 out of 780 students agreed to fill in the questionnaire (a sample large enough to perform reliable structural equation models [46]). Data from one participant were discarded, since 
they obviously provided incorrect data (e.g., being 69 years of age). Of the 639 remaining participants, 318 were female and 321 were male. There were 237 who reported being in first year, 202 in second year and 200 in third (and last) year. Participants' ages ranged from 14 to 22 , with most of them being underage $(M=16.85, S D=1.36$; note that because four participants did not indicate their age, missing data were replaced with the mean age of the corresponding school year).

\subsubsection{Measures}

The questionnaire was comprised of 51 items. The first four questions measured sociodemographic (i.e., gender and age) and school-related (e.g., year, identification number) information. Then, 43 items (all listed in Appendix A) measured the components of the VBN model. In all cases, possible responses ranged from 1 (no agreement at all) to 5 (fully agree). Existing translations in French were used; if no translation was available, items were translated for the purpose of the present study. Note that three items measuring attributing environmental issues to fate were not used in the present study. In addition, at the end of the questionnaire an item was added at the high school request: Students were invited to indicate to which extent they thought that the classes they attended help them to understand sustainability-related issues. This question was not analysed in the present article.

First, as for values, eighteen items inspired by the revised Portrait Value Questionnaire $[19,47]$ were used to measure biospheric ( 3 items), altruistic ( 3 values-universalism concern, benevolence-caring and benevolence-dependability -3 items each) and egoistic (3 values-power-resources, power-dominance, and achievement-two items each) values. These items were used to evaluate extent to which high schoolers give priority to biospheric values. Priority scores are common practice in value research $[48,49]$ and we calculated each individual's average score for all value types aggregated and then subtracted their global value average from their average for biospheric values; $70.01 \%$ of the participants granted more importance to biospheric values.

Second, as for beliefs, four items were created to measure students' general ecological beliefs. Awareness of the consequences of climate change (AC) was measured with 6 items from the environmental threat scale by Milfont and Duckitt [50]. Two different scales were then used to measure ascription of responsibility (AR). On the one hand, to measure the internal and external locus of control, we adapted a short version of the Internal, Powerful Others, and Chance scales [51]. On the other hand, to complement internal locus of control, we used six items that measured high school students' feelings of self-efficacy. Indeed, although meta-analytical evidence showed that locus of control and generalized self-efficacy are strongly related and have poor discriminant validity [52], recent research revealed that specific environmental self-efficacy is a crucial element when collective forms of control are used to predict pro-environmental behaviour $[53,54]$. Thus, since Levenson's internal locus of control items [51] are rather general, we added an environmental self-efficacy scale that focused on six specific behaviours (see Appendix A). Third, we measured the moral obligation to act for the environment that participants attribute to their generation, to their parents' and to their grandparents' generations with three items.

Finally, students' engagements in two actual pro-environmental behaviours were matched with their responses to the questionnaire. First, during the sustainability day, students were given a separate sheet of paper, with the school's logo only, which invited them to state whether they were willing to commit to pro-environmental actions in the school. This form was to be signed and returned to the headmaster. Thirty-one students did so. Second, a project of a local permaculture garden was also initiated during the event. In the following months, teachers recorded the names of the twenty-two students who actually showed up to work on the permaculture garden. Only three students were engaged in both behaviours. Data for both behaviours were collected by the school, and a rigorous procedure was followed to ensure participants' anonymity. First, the students school identification number was printed on the questionnaire, which was in the research 
team's hands and not accessible to anyone from the school. Second, the behavioural data were collected and stored only by the school, with no access to the research team. Third, a research assistant, who did not participate in the other stages of the study and did not know anyone at that high school, matched the data at the school registrar's office.

\subsection{Results}

\subsubsection{Measurement Model}

A confirmatory factor analysis (CFA) was conducted with MPlus 8 [55] to see whether the constructs that were measured with more than one item were distinct enough. Preliminary analyses indicated a strong relationship between ecological worldviews and awareness of consequences (i.e., a CFA model considering all items as forming one single latent variable did not differ significantly from one making a distinction between the two concepts). For this reason, items measuring these two concepts were collapsed into a single latent variable, which we called ecological beliefs (note that all SEM results were similar in substance if ecological worldview and awareness of consequences were treated as two separate constructs). In addition, regarding the moral obligation measure, a preliminary examination revealed that the three items were positively correlated $(r s>0.30$, $\alpha=0.76$ ), which suggests that participants saw all generations are jointly responsible (i.e., the "intergenerational obligation" scenario). The three items were thus set to form one factor in the CFA. Thus, the CFA contained the following variables: ecological beliefs (one variable), internal and external locus of control (two variables), self-efficacy (one variable), and intergenerational obligation (one variable).

Results indicated that at first the model did not fit the data adequately, $\chi^{2}(265)=679.39$, $p<0.001, \mathrm{CFI}=0.865$, RMSEA $=0.049$. Indeed, models are generally considered to fit the data when the Comparative Fit Index (CFI) is higher than 0.950 and the Root Mean Square of Error of Estimation (RMSEA) is lower than 0.060 [56,57]. Examination of the modification indices (MI, which indicate to what extent modifications in the model parameters will lead in a decrease in the chi-square value) revealed that some modifications could improve the model fit. First, the greatest decrease in chi-square value (i.e., 85.65) could be obtained if the errors of two items measuring awareness of consequences ( $a c$ _inter and $a c \_a b u s$, see Appendix A for the variable list) were allowed to correlate. A closer examination of the AC item loadings revealed that ac_abus was more weakly related to the latent construct than all other items measuring awareness of consequences. For this reason, ac_abus was no longer included in the model. Second, loc_int_imp and loc_int_act-two items used to measure participants' internal locus of control-were found to cross-load on several other latent constructs (i.e., awareness of consequences, self-efficacy, and intergenerational obligation). For this reason, the internal locus of control was omitted and only the self-efficacy latent variable was kept in the model to measure participants' beliefs that they feel able to act to limit climate change. Finally, as suggested by the MI, error terms were correlated between several pairs of items (i.e., ew_harm and ew_poll; ac_growth and ac_collap; selfe_transp and selfe_recycl, int_obl_par and int_obl_own/int_obl_par). The resulting model was found to fit the data adequately: $\chi^{2}(177)=269.79, p<0.001, \mathrm{CFI}=0.962$, RMSEA $=0.029$. The correlations between the scores are presented in Appendix B.

\subsubsection{Structural Model}

Several one-item variables were added to the model described above to test the relationships between the VBN components and pro-environmental behaviours hypothesized in the theoretical model. First, the relative importance granted to biospheric values was entered as a predictor of ecological beliefs and the other components of the models, since values are known to impact pro-environmental behaviours both indirectly and directly. Age and gender were used as control variables (note that only significant effects of the control variables were retained in the final model). Finally, the two dependent variablesenvironmental commitment and permaculture gardening-were specified as categorical 
dependent variables (which is allowed by Mplus in SEM), respectively did not commit (0) vs. committed (1), and did not participate (0) vs. participated (1).

Results of the final model, $\chi^{2}(278)=412.06, p<0.001, \mathrm{CFI}=0.953, \mathrm{RMSEA}=0.027$, are summarized in Figure 2. Consistent with predictions from the VBN theory, the higher the priority high schoolers granted to biospheric values (relative to altruistic and egoistic values), the more they held ecological beliefs, $\beta=0.43, p<0.001 ; 95 \%$ CI $(0.36,0.51)$. Biospheric values were also significantly related to greater environmental self-efficacy, $\beta=0.47, p<0.001 ; 95 \%$ CI $(0.39,0.55)$. Then, and as found in adult samples, the more high schoolers who held ecological beliefs, the more they believed in their ability to act to limit climate change, $\beta=0.36, p<0.001 ; 95 \% \mathrm{CI}(0.26,0.45)$. Ecological beliefs were also positively related to young people's propensity to see the environment as in the hands of powerful others, $\beta=0.21, p<0.001 ; 95 \% \mathrm{CI}(0.09,0.33)$. However, holding an external locus of control (powerful others) did not significantly relate to perceptions of intergenerational obligation, $\beta=0.07, p=0.31$; $95 \% \mathrm{CI}(-0.06,0.20)$.

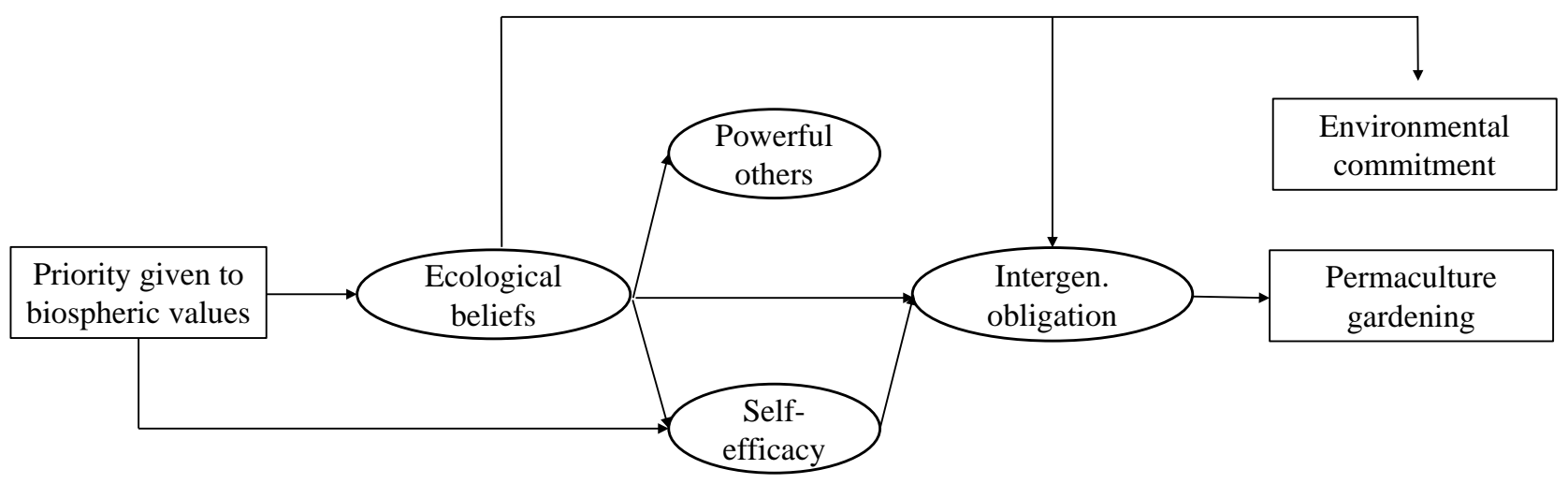

Figure 2. Summary of Study 1 results. Arrows depict significant relationships. Since we had no specific prediction regarding gender and age, these effects are not depicted here.

By way of contrast, the more young people who believed in their ability to act, the more they expressed feelings of collective obligation: $\beta=0.36, p<0.001 ; 95 \% \mathrm{CI}(0.21$, $0.50)$; note that the latter was also directly related to ecological beliefs; $\beta=0.37, p<0.001$; $95 \%$ CI $(0.21,0.53)$. Intergenerational obligation was significantly related to an increased likelihood that young people actually participated in the permaculture gardening activity, $\beta=0.26, p=0.001 ; 95 \% \mathrm{CI}(0.11,0.42)$. The other behaviour considered-pro-environmental commitment-was not significantly related to intergenerational obligation, $\beta=-0.05$, $p=0.54 ; 95 \% \mathrm{CI}(-0.20,0.11)$, but directly to ecological beliefs, $\beta=0.23, p=0.001 ; 95 \% \mathrm{CI}$ $(0.09,0.37)$.

Indirect paths were then estimated. When it comes to participation in the permaculture gardening activity, the whole VBN chain - values, beliefs, self-efficacy, and intergenerational solidarity-yielded a significant effect: $\beta=0.01, p=0.02,95 \% \mathrm{CI}(0.00$, $0.03)$. Note that two other indirect paths yielded significant estimates: values-ecological beliefs-intergenerational obligation-gardening, $\beta=0.04, p=0.02,95 \% \mathrm{CI}(0.01,0.08)$ and values-self-efficacy-intergenerational obligation-gardening, $\beta=0.04, p=0.02,95 \% \mathrm{CI}(0.01$, $0.08)$. When it comes to pro-environmental commitment, the only significant indirect path started from values and went through ecological beliefs, $\beta=0.10, p=0.01,95 \% \mathrm{CI}$ $(0.04,0.17)$.

Finally, male students hold lower scores of ecological beliefs, $\beta=0.18, p<0.001,95 \%$ CI $(-0.27,-0.10)$, higher scores of locus of control-powerful others, $\beta=-0.14, p=0.008$, $95 \%$ CI $(0.04,0.24)$, and a stronger probability to have committed themselves to proenvironmental actions, $\beta=-0.12, p=0.002,95 \% \mathrm{CI}(0.05,0.20)$. Being older was positively related to an external locus of control, $\beta=0.17, p<0.001,95 \% \mathrm{CI}(0.08,0.27)$, and to a stronger environmental commitment, $\beta=0.09, p=0.02,95 \% \mathrm{CI}(0.02,0.17)$. Note that 
a model excluding gender and age yielded similar estimates (i.e., all significant effects remained significant, and all non-significant effects remained non-significant).

\subsection{Discussion}

Echoing findings from previous research on adult samples, the results of Study 1 confirmed that giving the priority to biospheric values was found to underlie ecological beliefs among young people. These beliefs then translated into both feeling able to act to limit climate change (i.e., heightened perceptions of self-efficacy) and seeing the fate of the environment in the hands of powerful others. However, only feelings of self-efficacy were related to participants' perceptions of intergenerational responsibility. Moving on, perceiving that all generations should act to limit climate change was related to high schoolers' actual attendance to a local permaculture gardening activity, but not to a generic commitment to pro-environmental actions on the school grounds (which was directly and positively related to their ecological beliefs).

While this first study provides an insight on how perceptions of intergenerational obligation may outweigh perceptions of helplessness in shaping one of the behaviours under investigation, the timing of the study as well as the measures used may have affected the results. Indeed, Study 1 data were collected in Autumn 2016, prior to the large-scale climate protests that happened all over the world. Ecological concerns were nevertheless quite salient at that time, and even more in participants' mind because they were invited to fill in the questionnaire a few hours after seeing a documentary movie that opens with a realistic (and thus grim) portrait of the actual state of the environment, and then present concrete individual and collective solutions to tackle climate change (Demain/Tomorrow, by Cyril Dion and Mélanie Laurent). While fear-based messages are likely to backfire [58], exposure to both abstract and concrete information may enhance individuals' self-efficacy and willingness to act to limit climate change [59]. This enhanced sense of agency may account for the non-significant links between external locus of control and the later stages of the model (i.e., intergenerational obligation and behaviours). Another important fact that must be taken into account is that Study 1 data were collected before the COVID-19 pandemic started. Personal experience with COVID-19 appears to be related to a stronger motivation to support environmental policies and taxes in the US [60]; climate perceptions and anti- COVID-19 behaviours were also found to be linked [61].

Regarding the measures themselves, the two items measuring the obligation attributed by young people to older generations referred to their parents' and grandparents' generations. Because of that, some respondents may have responded as a function of how they perceive their relatives' behaviours. In addition, the intergenerational obligation measure may have tapped into the fact that participants felt that all generations are more efficient when coordinating their efforts (hence measuring perceptions of collective efficacy), and not the fact regardless of one's age and contribution to environmental damage, it is the obligation of all generations to act together. In addition, only a small percentage of the participants were engaged in the two behaviours under consideration. Finally, only participation in a gardening activity related to perceptions of intergenerational obligation. This activity may have stemmed from heightened feelings of self-efficacy and perceptions of collective moral obligation because of its concreteness, whereas unspecific commitment to pro-environmental actions in the school (such as signing the form for the headmaster) may correspond to more generic pro-environmental beliefs because they are at the same level of generality.

For these reasons, we conducted a second study, aiming at replicating these results while addressing the above limitations. While we did not have enough space to include all the value items used (but only a few measuring biospheric values; see Section 3.1.1), the other measures were similar, or improved, in comparison with Study 1. In particular, we made sure that the obligation items measured participants' attributed responsibility to different generations (e.g., people who are currently under 25, between 25 and 45, and so on) and did not mention relatives. Moreover, to verify that our measure of intergenerational 
obligation was not in fact a measure of perceived collective efficacy, additional questions were added to measure students' perceptions of generations' power and knowledge about climate change. Finally, students' willingness to participate in compulsory additional and non-credited courses on sustainability - which was likely to result in a less skewed dependent variable — was used as a measure of concrete behavioural commitment.

\section{Study 2}

3.1. Method

\subsubsection{Procedure and Participants}

The items reported here were embedded in a questionnaire sent to all students (around 12,000) of a French-speaking Swiss University in May 2020 by one of the Vice-Presidents, to measure whether they wanted more courses in sustainable development in their curriculum. Because the questionnaire was sent to all students, we were asked not to include too long scales. Participants were made aware that their responses could be used for research purposes. Altogether, 3764 students started filling in the questionnaire, and 2771 completed it. Data from bachelor students under 25 were selected both because their age was closer to that of Study 1 sample, corresponded to the first category mentioned in the intergenerational obligation scale (see below), and because the dependent variable, i.e., their willingness to have additional courses in their curriculum, was more relevant for students who were not about to finish their studies. The final sample $(n=1509)$ was composed of students aged between 18 and $24(M=21.54, S D=1.46 ; 1052$ women and 457 men $)$.

\subsubsection{Measures}

All items used in Study 2, along with their means and standard deviations, are displayed in Appendix C. Biospheric values were measured with four items. Two were identical to those used in Study 1. The item about participating in environmental actions was discarded because of its behavioural component. Instead, two items measuring the importance granted by participants to feel in harmony with the environment were added [34]. Nine of the ten items used to measure ecological beliefs in Study 1 were used here (ac_inter was no longer used, since it was discarded in Study 1). External locus of control and personal self-efficacy were measured with the same items as in Study 1.

When it comes to intergenerational obligation, participants were asked to estimate to what extent four groups of people were to help the environment: people under 25, people aged between around 25 and 45, people aged between around 46 and 65, and people over 65. Two questions using the same groups were then asked to measure participants' perceptions of collective efficacy, by estimating to what extent the generations have the financial or political means (first item), and the knowledge (second item) to limit current environmental issues. Finally, participants' willingness to have compulsory extra (and non-credited) courses in their curriculum was measured, which can be considered as a costly commitment. Indeed, in addition to research purposes, the above questionnaire was embedded in an official survey sent by one of the university's Vice-Presidents, which was intended to plan future courses on sustainability for the whole university. They first answered 'yes' or 'no' (43.1\%) to whether they wanted such extra courses. In case they said 'yes', they were asked how much time each week they were willing to attend such courses, that is less than one hour $(14.9 \%)$, between one and three hours $(37.9 \%)$, or more than three hours $(4.1 \%)$. The two variables were combined into one, ranging from 0 to 3.

\subsection{Results}

\subsubsection{Measurement}

As in Study 1, a confirmatory factor analysis (CFA) was conducted on a model that included the constructs that were measured with more than one item, that is biospheric values, ecological beliefs, external locus of control, self-efficacy, and intergenerational obligation. Regarding the latter, as in Study 1, a preliminary analysis revealed that the four items (i.e., int_obl_u25, int_obl_2545,int_obl_4665, and int_obl_ov65) were positively 
correlated ( $r s>0.49, \alpha=0.86$ ), which suggests that Study 2 participants also saw all generations are jointly obligated to help the environment. Moreover, an exploratory factor analysis revealed that these two collective efficacy variables were distinct from the measure of intergenerational vs. generational obligation (three factors yielded an eigenvalue over 1 and loadings ranged from 0.69 to 0.92 , with one exception, i.e., int_know_u25, 0.47).

CFA results indicated that the model did not fit the data adequately: $\chi^{2}(289)=1771.49$, $p<0.001, \mathrm{CFI}=0.918$, RMSEA $=0.042$. Examination of MI indicated that, to improve the model fit, correlations between five pairs of items should be allowed (i.e., between val_bio_harm and val_bio_ad, ew_harm and ac_growth, ac_collap and ac_growth,int_obl_2545 and int_obl_4665,int_obl_4665 and int_obl_ov65). The resulting model was found to fit the data adequately: $\chi^{2}(284)=951.33, p<0.001, \mathrm{CFI}=0.963$, RMSEA $=0.039$. The correlations between the scores are presented in Appendix D.

\subsubsection{Structural Model}

The dependent variable, and age and gender (both as controls) were added to the structural model (as in Study 1, only significant or marginally significant effects were retained in the final model). Results of the final model, $\chi^{2}(333)=1106.06, p<0.001$, $\mathrm{CFI}=0.958, \mathrm{RMSEA}=0.039$, are summarized in Figure 3. Results of Study 1 were replicated. First, biospheric values were again related to stronger ecological beliefs, $\beta=0.68, p<0.001$; $95 \%$ CI $(0.65,0.72)$, and to a greater environmental self-efficacy, $\beta=0.49, p<0.001 ; 95 \%$ CI (0.43 0.56). Then, students' ecological beliefs were related to a greater perceived ability to act to limit climate change, $\beta=0.27, p<0.001 ; 95 \% \mathrm{CI}(0.20,0.34)$, and to a stronger external locus of control, $\beta=0.45, p<0.001 ; 95 \%$ CI $(0.40,0.51)$. Again, a greater sense of self-efficacy was related to a stronger sense of intergenerational moral obligation, $\beta=0.21$, $p<0.001 ; 95 \%$ CI $(0.13,0.29)$, which was, in a turn, related to a greater willingness to attend additional non-credited courses on sustainability, $\beta=0.07, p=0.03$; 95\% CI $(0.01,0.12)$.

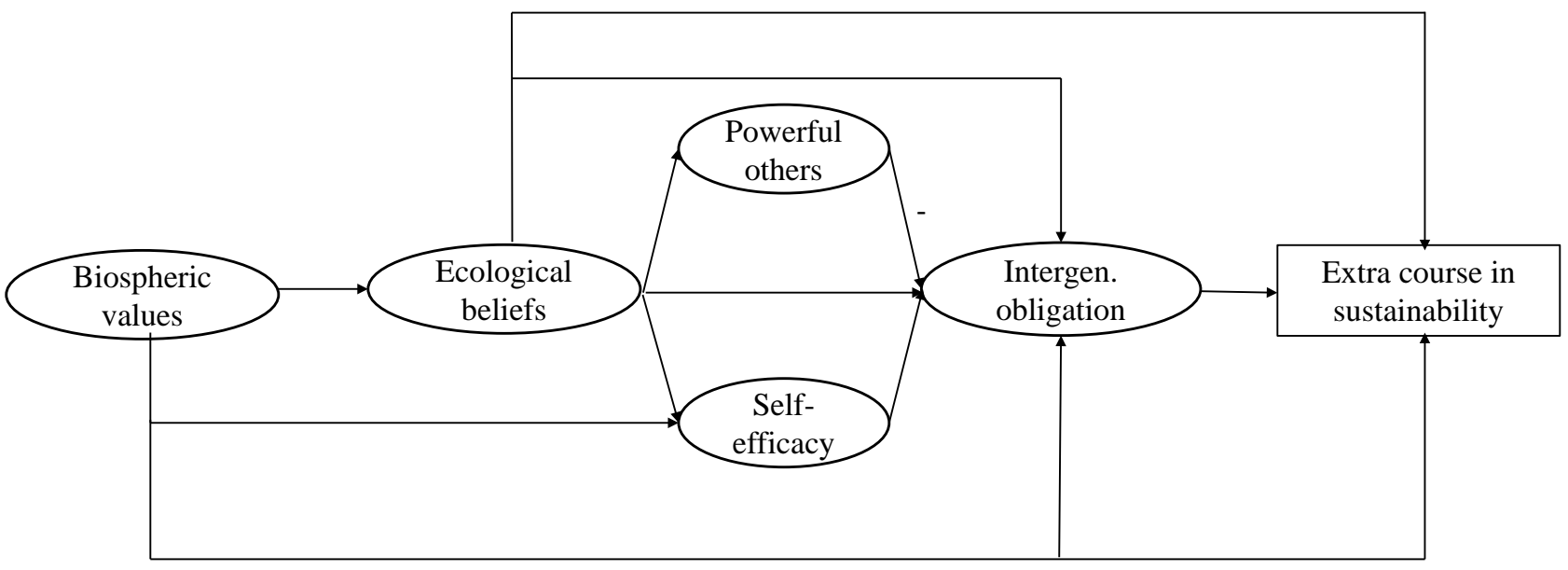

Figure 3. Summary of Study 2. Arrows depict significant relationships. Since we had no specific prediction regarding gender and age, these effects are not depicted here.

As for indirect paths from biospheric values to the dependent variable, as in Study 1 , the whole VBN chain-values, beliefs, self-efficacy, and intergenerational obligationyielded a significant effect: $\beta=0.01, p=0.05,95 \%$ CI $(0.00,0.01)$. Two other indirect links revealed in Study 1 were also significant in Study 2: biospheric values were indirectly related to the dependent variable through heightened ecological beliefs, $\beta=0.11$, $p<0.001,95 \% \mathrm{CI}(0.06,0.16)$, and through a stronger sense of self-efficacy and perceptions of intergenerational obligation, $\beta=0.01, p=0.05,95 \% \mathrm{CI}(0.00,0.01)$.

The results of Study 2 revealed additional significant relationships. First, both biospheric values, $\beta=0.24, p<0.001 ; 95 \%$ CI $(0.17,0.32)$, and ecological beliefs, $\beta=0.16$, $p<0.001 ; 95 \%$ CI $(0.08,0.24)$ were directly related to a greater willingness to attend extra 
courses on sustainability. Second, participants with strong biospheric values, $\beta=0.16$, $p<0.001 ; 95 \%$ CI $(0.07,0.25)$, and strong ecological beliefs, $\beta=0.23, p<0.001 ; 95 \% \mathrm{CI}$ $(0.14,0.32)$, along with those with a low external locus of control, $\beta=-0.12, p<0.001$; $95 \%$ CI $(-0.18,-0.05)$, reported a strong sense of intergenerational obligation. Finally, the values-beliefs-intergenerational obligation-willingness to attend courses on a sustainability indirect path also yielded a significant estimate, $\beta=0.01, p=0.04,95 \%$ CI $(0.00$, 0.02). Finally, regarding the control variables, men were found to express lower ecological beliefs, $\beta=0.10, p<0.001,95 \%$ CI $(0.06,0.15)$, and scored marginally significantly lower in self-efficacy, $\beta=0.04, p=0.07,95 \% \mathrm{CI}(-0.03,0.08)$ and intergenerational obligation, $\beta=0.05, p=0.07,95 \%$ CI $(-0.00,0.10)$.

\subsection{Discussion}

Overall, the results of Study 2 replicated the findings of Study 1, namely that perceptions of a collective and intergenerational moral obligation to act to limit climate change stem from biospheric values, ecological beliefs, and a sense of self-efficacy, and relate to students' propensity to engage into pro-environmental behaviours. We thus found similar results with measures of both actual behaviour (the permaculture activity in Study 1) and a costly commitment (Study 2). In addition, biospheric values were also directly related to students' willingness to attend extra courses in sustainability, which indicates that other mediating processes than those studied in the present research may have been at play (similar to Study 1, biospheric values directly predicted the behaviour of signing a commitment to engage in sustainable activities in the school, addressed to the school headmaster). Finally, the present study not only shows, same as Study 1, that perception of intergenerational obligation is a relevant construct to understand the collective processes that lead to commitment and behaviour, but it also specifies that such a construct is different from perceptions of collective efficacy.

In contrast to Study 1, bachelor students who thought that the fate of the environment is in the hands of powerful others (politicians, companies, and scientists) reported a lower sense of moral obligation that all generations must act to limit climate change. Despite that, this perceptions of an external locus of control did not significantly translate into a lower willingness to follow extra courses. In other words, perception of intergenerational obligation suffers from knowing that powerful others are in fact in charge, but remains strong enough to predict pro-environmental commitment.

\section{General Discussion}

Because of their age and life situation, young people-and especially those still in education - may feel unable to act to limit climate change, seen in the hands of powerful others, such as companies and politicians. If so, they may attribute the responsibility to act to older generations rather than to their own, and refrain from engaging in pro-environmental behaviours. To examine this largely understudied possibility and evaluate through which mechanisms young people may engage themselves, we conducted a questionnaire study with two large samples of high school and bachelor students. To this effect, we extended the usual components of the VBN theory to incorporate measures of constructs that are likely to matter for adolescents' attitudes and behaviours. Results of the two studies showed that young people's biospheric values and ecological beliefs in fact predict self-efficacy and result in pro-environmental commitment and behaviour via heightened perceptions that all generations united must act for the environment.

\subsection{When Youth Face Climate Change: Helplessness vs. Agency}

Previous research has suggested that people of all age tend to feel helpless and without resources to face climate change [62]. Feelings of helplessness are even more acute among the youth, by the lack of agency that children, adolescents and even young adults often experience [12]. For this reason, it has been argued that fear appeals-such as describing the true extent of current and probable environmental issues-are likely to trigger despair 
among young audiences [12]. Studies suggest indeed that hope-defined as a mix of perceived self-efficacy (believing in one's own ability to act) and pathways (believing that there are means to reach a given goal [63])_are necessary conditions for young people to engage in pro-environmental actions [64]. Trust in societal actors appears to also play an important role in both promoting hope [65] and helping young people to cope with climate change-induced despair [66]. For this reason, it is all the more important to consider whether young people see the environment in their hands or in the hands of powerful others, and if so, how this affects their propensity to act in favour of the environment.

The first contribution of the present research consists of the result that believing that the environment is in the hands of powerful others does not preclude a sense of agency among youth. Indeed, we found that adolescents and young adults most aware of environmental issues both attributed to a greater extent control over the environment to companies, politicians, and scientists, and scored high in environmental self-efficacy. Importantly, the impact of perceived personal self-efficacy appears to outweigh the role played by adopting an external locus of control in predicting behaviour, since only the former was indirectly related to the measures of actual behaviour and behavioural commitment. These results suggest that the educational system and other actors directly in interacting with adolescents should not refrain from showing the true extent of environmental damages to (relatively) young audiences, as this may bring them to experience agency, and ultimately display pro-environmental behaviours. This is in line with recent research that argues that biospheric values and awareness of the consequences of climate change are linked to efficacy beliefs, and ultimately mitigative actions, a relationship that interestingly might hold for both climate change-related actions and responses to COVID-19 [67].

\subsection{All in the Same Boat? Representations of an Intergenerational Obligation}

Questions about who bears the responsibility for current and future environmental issues-and, therefore, who should act to address them-appeal to the notion of justice, which is central to the study of the psychological processes underlying individual reactions to climate change $[68,69]$. Indeed, because natural resources are finite, a fair treatment would imply an equal access to them. This is far from being the case. Indeed, those who are contributing or will contribute less to environmental issues are often also those who are suffering or will suffer most from them: young people of today and future generations (intergenerational justice), people from developing countries (global justice), and non-human living entities (ecological justice [70]). Research showed that the extent to which individuals perceive these injustices and their willingness to act to repair them affect their pro-environmental attitudes and behaviours. For instance, thinking that resources should be fairly managed so future generations are not too adversely affected-a belief that tends to predominate over other justice beliefs [71] — has been linked to higher levels of proenvironmental attitudes and behavioural intentions (see [69] for a review), through feelings of responsibility and anger [70]. The second contribution of the present study is to go a step further and investigate how individuals, here young people, perceive interdependence between generations and how such perceptions relate to pro-environmental commitment and behaviour.

The present results provide empirical evidence for a phenomenon we here termed "intergenerational obligation". When asked to provide their opinion as to the extent to which different generations are responsible to act to help the environment, our participants did not appear to favour an "us vs. them" scenario. Echoing findings from studies that showed that "rather than intergenerational and intragenerational fairness being alternatives, they are seen by the public as being complementary" [69] (pp. 912-913), the amount of responsibility adolescents and young adults attributed to each generation covaried positively, indicating that they perceive a community of moral obligation. Most importantly, such a perception of positive interdependence was related to a higher probability to engage in an actual pro-environmental behaviour and in a costly educational commitment. 


\section{Conclusions}

We believe that this study represents an important contribution to the prediction of pro-environmental behaviours, in that it allows for complementing the widely used VBN predictors with a collective-level variable-intergenerational obligation - that may help move this line of research towards the consideration of more collective mechanisms [14]. The study of intergenerational obligation may yield important practical consequences by helping understandings of a phenomenon that has just started to attract scholars' attention, namely the influence that children may have on their parents' climate change concerns [72]. Indeed, fostering a more collective representation of environmental responsibility in youth may not only have the long-term effect of creating a more responsible generation of future decision makers, but possibly the shorter-term effect of involving the other generations in this effort, starting from today. Educators and policy makers may find these results useful to design new educational materials that promote a more inclusive representation of environmental responsibility and, hopefully, more pro-environmentally committed students.

Author Contributions: Conceptualization, O.S., F.C.v.R. and F.B.; Data curation, O.S.; Formal analysis, O.S.; Funding acquisition, O.S., F.C.v.R. and F.B.; Methodology, O.S.; Project administration, O.S.; Supervision, F.B.; Writing—original draft, O.S.; Writing—review \& editing, O.S., F.C.v.R. and F.B. All authors have read and agreed to the published version of the manuscript.

Funding: The present research received support from a Volteface grant (https:/ /www.volteface.ch/ accessed on 20 January 2022), awarded by the University of Lausanne, the Canton of Vaud and la Romande Energie.

Institutional Review Board Statement: Permission from an ethical committee was not requested (it was not necessary given extant regulations for the social sciences in Switzerland), but the study was approved by the school headmaster and the teachers involved in the event. Moreover, all parents were informed that their children (in case the latter were underage) would be invited to participate in a study. No parents refused.

Informed Consent Statement: Informed consent was obtained, although not in written form, to the extent that the questionnaire was part of a school activity that was explained in detail by the school to the students and the parents.

Data Availability Statement: Data are available from the corresponding author on request.

Acknowledgments: The authors wish to thank Vanessa Bongcam and Augustin Fragnière for invaluable help and access to the two samples, and Linda Steg for constructive comments on the project.

Conflicts of Interest: The authors declare no conflict of interest.

\section{Appendix A}

Items used in Study 1, along with means and standard deviations.

Values. It is important to me ...

\begin{tabular}{llll} 
Biospheric values $(\alpha=0.76)$ & \\
\hline val_bio_nat & to care for nature & 4.62 & 0.67 \\
\hline val_bio_act & to participate in actions to defend nature & 3.38 & 1.01 \\
\hline val_bio_destr & to protect the environment from destruction or pollution & 4.08 & 0.89 \\
\hline
\end{tabular}




\begin{tabular}{|c|c|c|c|}
\hline & & $\mathbf{M}$ & SD \\
\hline \multicolumn{4}{|c|}{ Altruistic values } \\
\hline val_alt_opp & that every person in the world have equal opportunities in life ${ }^{\text {a }}$ & 4.47 & 0.81 \\
\hline val_alt_treat & that everyone is treated justly, even people I do not know ${ }^{\text {a }}$ & 4.62 & 0.70 \\
\hline val_alt_pro & that society's weak and vulnerable members are protected ${ }^{a}$ & 4.31 & 0.91 \\
\hline val_alt_help & to help the people dear to me ${ }^{b}$ & 4.79 & 0.55 \\
\hline val_alt_close & to care for people I am close to ${ }^{b}$ & 4.65 & 0.62 \\
\hline val_alt_dear & to be responsive to the needs of those dear to me ${ }^{b}$ & 4.03 & 0.96 \\
\hline val_alt_trust & that people I know trust me fully ${ }^{\mathrm{c}}$ & 4.57 & 0.75 \\
\hline val_alt_fr & to be a dependable and trustworthy friend ${ }^{\mathrm{c}}$ & 4.77 & 0.58 \\
\hline val_alt_rely & that all my friends and family members are able to rely on me completely & 4.46 & 0.81 \\
\hline \multicolumn{4}{|l|}{ Egoistic values } \\
\hline val_ego_money & to have the power that money can bring ${ }^{d}$ & 2.91 & 1.13 \\
\hline val_ego_obj & to have expensive objects that show my wealth ${ }^{d}$ & 1.85 & 1.02 \\
\hline val_ego_tell & that people do what I tell them to do ${ }^{\mathrm{e}}$ & 2.81 & 0.70 \\
\hline val_ego_power & to have the power to make people do what I want to ${ }^{\mathrm{e}}$ & 1.89 & 1.07 \\
\hline val_ego_amb & to have ambitions in life ${ }^{f}$ & 4.55 & 0.71 \\
\hline val_ego_achiev & that people acknowledge my achievements $f$ & 3.51 & 1.17 \\
\hline \multicolumn{4}{|c|}{ Ecological worldviews ( $\mathrm{R}$ = scores were reversed) } \\
\hline ew_harm & The harms inflicted on biodiversity by human activities are minor (R) & 4.20 & 1.01 \\
\hline ew_poll & The Earth is far more polluted than is generally thought & 3.98 & 0.97 \\
\hline$e w \_c o 2$ & Human activity on Earth must produce less $\mathrm{CO} 2$ & 4.14 & 0.92 \\
\hline ew_over & Generally humans are overconsuming the resources that are available to them & 4.44 & 0.76 \\
\hline \multicolumn{4}{|c|}{ Awareness of consequences ( $\mathrm{R}=$ scores were reversed $)$} \\
\hline ac_cat & $\begin{array}{l}\text { If things continue on their present course, we will soon experience a major } \\
\text { ecological catastrophe }\end{array}$ & 4.30 & 0.80 \\
\hline ac_growth & $\begin{array}{l}\text { I cannot see any real environmental problems being created by rapid economic } \\
\text { growth. It only creates benefits }(\mathrm{R})\end{array}$ & 3.96 & 0.93 \\
\hline ac_inter & When humans interfere with nature it often produces disastrous consequences & 3.32 & 1.04 \\
\hline ac_abus & Humans are severely abusing the environment & 3.83 & 0.90 \\
\hline ac_balanc & The balance of nature is very delicate and easily upset & 3.67 & 1.00 \\
\hline ac_collap & $\begin{array}{l}\text { People who say that the unrelenting exploitation of nature has driven us to the } \\
\text { brink of ecological collapse are wrong (R) }\end{array}$ & & \\
\hline \multicolumn{4}{|c|}{ Environmental Locus of Control } \\
\hline \multicolumn{4}{|l|}{ Internal } \\
\hline loc_int_imp & $\begin{array}{l}\text { When I engage in a pro-environmental behaviour, I am sure that it has a real } \\
\text { impact on the environment }\end{array}$ & 3.11 & 1.04 \\
\hline loc_int_able & In general I feel that I am able to protect the environment & 2.94 & 1.11 \\
\hline loc_int_act & I am convinced that my actions partly determine the state of the Earth & 3.13 & 1.14 \\
\hline \multicolumn{4}{|c|}{ Powerful others } \\
\hline low_pow_pol & $\begin{array}{l}\text { I feel that what is happening to the environment is mostly determined by } \\
\text { people who have political power }\end{array}$ & 3.37 & 1.11 \\
\hline low_pow_comp & The state of the Earth is mostly under companies' control & 3.26 & 1.08 \\
\hline low_pow_scien & Without the intervention of scientists nothing is attempted to pollute less & 2.62 & 1.13 \\
\hline
\end{tabular}




\section{SD}

\begin{tabular}{|c|c|c|c|}
\hline \multicolumn{4}{|c|}{ Environmental self-efficacy. I feel that I am able... } \\
\hline selfe_contr & to reduce my contribution to climate change & 3.53 & 0.91 \\
\hline selfe_dev & to ensure that my contribution to sustainable development is greater & 3.87 & 0.91 \\
\hline selfe_poll & to overcome obstacles that hinder me to pollute less & 3.82 & 0.86 \\
\hline selfe_electr & to reduce my electricity use & 3.51 & 1.15 \\
\hline selfe_transp & to use more often public transportation & 4.14 & 1.21 \\
\hline selfe_recycl & to overcome obstacles that hinder me to recycle more & 4.11 & 0.93 \\
\hline \multicolumn{4}{|c|}{ Intergenerational obligation } \\
\hline int_obl_own & It is my generation's responsibility to help the environment & 4.10 & 1.06 \\
\hline int_obl_par & It is the responsibility of my parents' generation to help the environment & 3.67 & 1.11 \\
\hline int_obl_grand & It is the responsibility of my grandparents' generation to help the environment & 3.02 & 1.35 \\
\hline
\end{tabular}

Note. ${ }^{\mathrm{a}}$ universalism concern $(\alpha=0.79),{ }^{\mathrm{b}}$ benevolence-caring $(\alpha=0.67),{ }^{\mathrm{c}}$ benevolence- dependability $(\alpha=0.71)$

$\mathrm{d}$ power-resources $(r=0.38)$, ${ }^{\mathrm{e}}$ power dominance $(r=0.47),{ }^{\mathrm{f}}$ achievement $(r=0.14)$.

\section{Appendix B}

Correlations between composite scores, Study 1.

\begin{tabular}{|c|c|c|c|c|c|c|c|c|}
\hline & Values & Beliefs & $\begin{array}{l}\text { External } \\
\text { Control }\end{array}$ & $\begin{array}{c}\text { Self- } \\
\text { Efficacy }\end{array}$ & $\begin{array}{c}\text { Inter. } \\
\text { Obligation }\end{array}$ & Commitment & Gardening & Sex \\
\hline Beliefs & $0.10 *$ & & & & & & & \\
\hline External control & 0.06 & $0.10 *$ & & & & & & \\
\hline Self-efficacy & $0.53^{* * *}$ & $0.19^{* * *}$ & 0.04 & & & & & \\
\hline Inter. Obligation & $0.28^{* * *}$ & $0.09 *$ & $0.09 *$ & $0.32 * * *$ & & & & \\
\hline Commitment & 0.10 * & $0.08^{+}$ & 0.00 & $0.08^{*}$ & 0.04 & & & \\
\hline Gardening & $0.13 *$ & -0.01 & 0.02 & 0.13 & $0.17^{* * *}$ & $0.08^{+}$ & & \\
\hline Sex (female) & $0.08 *$ & $0.15^{* * *}$ & -0.06 & $0.14^{* * *}$ & $0.10^{* *}$ & $-0.08^{\dagger}$ & 0.02 & \\
\hline Age & -0.04 & 0.04 & $0.11^{* *}$ & -0.03 & -0.02 & 0.09 & 0.01 & 0.01 \\
\hline
\end{tabular}

\section{Appendix C}

Items used in Study 2, along with means and standard deviations.

\begin{tabular}{|c|c|c|c|}
\hline & & $\mathbf{M}$ & SD \\
\hline \multicolumn{4}{|c|}{$\begin{array}{l}\text { Values It is important to me ... } \\
\text { Biospheric values }\end{array}$} \\
\hline val_bio_destr & to protect the environment from destruction or pollution & 5.46 & 0.86 \\
\hline val_bio_harm & to live in harmony with other species ${ }^{\text {a }}$ & 5.29 & 0.98 \\
\hline val_bio_ad & to live in harmony with nature ${ }^{\text {a }}$ & 5.04 & 1.12 \\
\hline val_bio_nat & to care for nature & 5.50 & 0.79 \\
\hline \multicolumn{4}{|c|}{ Ecological beliefs $(\mathrm{R}=$ scores were reversed $)$} \\
\hline ew_harm & The harms inflicted on biodiversity by human activities are minor (R) & 5.59 & 0.87 \\
\hline ew_poll & The Earth is far more polluted than is generally thought & 4.97 & 1.14 \\
\hline$e w \_c 02$ & Human activity on Earth must produce less $\mathrm{CO} 2$ & 5.42 & 0.93 \\
\hline
\end{tabular}




\begin{tabular}{llcc}
\hline & & M & SD \\
\hline ew_over & Generally humans are overconsuming the resources that are available to them & 5.49 & 0.93 \\
\hline ac_cat & $\begin{array}{l}\text { If things continue on their present course, we will soon experience a major } \\
\text { ecological catastrophe }\end{array}$ & 5.39 & 0.97 \\
\hline ac_growth & $\begin{array}{l}\text { I cannot see any real environmental problems being created by rapid economic } \\
\text { growth. It only creates benefits (R) }\end{array}$ & 5.50 & 0.89 \\
\hline ac_abus & Humans are severely abusing the environment & 5.26 & 1.05 \\
\hline ac_balanc & The balance of nature is very delicate and easily upset & 4.62 & 1.22 \\
\hline ac_collap & $\begin{array}{l}\text { People who say that the unrelenting exploitation of nature has driven us to the } \\
\text { brink of ecological collapse are wrong (R) }\end{array}$ & 5.19 & 1.20 \\
\hline
\end{tabular}

\section{Ascription of responsibility}

Powerful others

\begin{tabular}{llc} 
loc_pow_pol & $\begin{array}{l}\text { I feel that what is happening to the environment is mostly determined by } \\
\text { people who have political power }\end{array}$ & 4.49 \\
\hline loc_pow_comp & The state of the Earth is mostly under companies' control & 4.25 \\
\hline loc_pow_scien & Without the intervention of scientists nothing is attempted to pollute less & 3.58
\end{tabular}

Environmental self-efficacy. I feel that I am able...

\begin{tabular}{llll} 
selfe_contr & to reduce my contribution to climate change & 4.66 & 1.22 \\
\hline selfe_dev & to ensure that my contribution to sustainable development is greater & 4.88 & 1.08 \\
\hline selfe_poll & to overcome obstacles that hinder me to pollute less & 4.74 & 1.07 \\
\hline selfe_electr & to reduce my electricity use & 4.53 & 1.32 \\
\hline selfe_transp & to more often use public transportation & 5.11 & 1.33 \\
\hline selfe_recycl & to overcome obstacles that hinder me to recycle more & 5.18 & 1.05 \\
\hline
\end{tabular}

\section{Intergenerational obligation}

To which extent are these groups responsible to act for the environment?

\begin{tabular}{llcc}
\hline int_obl_u25 & People aged under 25 & 5.19 & 1.12 \\
\hline int_obl_2545 & People aged around between 25 and 45 & 5.37 & 0.95 \\
\hline int_obl_4665 & People aged around between 46 and 65 & 5.16 & 1.16 \\
\hline int_obl_ov65 & People aged more than 65 & 4.70 & 1.49 \\
\hline
\end{tabular}

\section{Collective efficacy}

To which extent do these groups have the financial or political means to limit current environmental issues?

\begin{tabular}{llcl}
\hline int_mean_u25 & People aged under 25 & 3.30 & 1.43 \\
\hline int_mean_2545 & People aged around between 25 and 45 & 4.88 & 1.09 \\
\hline int_mean_4665 & People aged around between 46 and 65 & 5.11 & 0.99 \\
\hline int_mean_ov65 & People aged more than 65 & 4.07 & 1.32 \\
\hline
\end{tabular}

To which extent do these groups have the necessary knowledge to limit current environmental issues?

\begin{tabular}{llcl}
\hline int_know_u25 & People aged under 25 & 4.82 & 1.21 \\
\hline int_know_2545 & People aged around between 25 and 45 & 4.97 & 1.04 \\
\hline int_know_4665 & People aged around between 46 and 65 & 4.45 & 1.25 \\
\hline int_know_ov65 & People aged more than 65 & 3.73 & 1.43 \\
\hline Willingness to attend additional non-credited courses on sustainability & \\
\hline tvol4 & Dependent variable & 1.03 & 0.99 \\
\hline
\end{tabular}




\section{Appendix D}

Correlations between composite scores, Study 2.

\begin{tabular}{|c|c|c|c|c|c|c|c|c|c|}
\hline & Values & Beliefs & $\begin{array}{l}\text { External } \\
\text { Control }\end{array}$ & $\begin{array}{l}\text { Self- } \\
\text { Efficacy }\end{array}$ & $\begin{array}{l}\text { Intergene- } \\
\text { Rational } \\
\text { Obligation }\end{array}$ & $\begin{array}{c}\text { Collective } \\
\text { Efficacy } \\
\text { Financial }\end{array}$ & $\begin{array}{c}\text { Collective } \\
\text { Efficacy } \\
\text { Knowledge }\end{array}$ & $\begin{array}{l}\text { Extra } \\
\text { Courses }\end{array}$ & Age \\
\hline Beliefs & $0.56^{* * *}$ & & & & & & & & \\
\hline External control & $0.27^{* * *}$ & $0.36^{* * *}$ & & & & & & & \\
\hline Self-efficacy & $0.59^{* * *}$ & $0.51^{* * *}$ & $0.24^{* * *}$ & & & & & & \\
\hline $\begin{array}{l}\text { Intergenerational } \\
\text { Obligation }\end{array}$ & $0.37^{* * *}$ & $0.36^{* * *}$ & $0.09^{* * *}$ & $0.38^{* * *}$ & & & & & \\
\hline $\begin{array}{l}\text { Collective } \\
\text { Efficacy } \\
\text { (Financial) }\end{array}$ & $0.30^{* * *}$ & $0.27^{* *}$ & $0.06^{*}$ & $0.33^{* * *}$ & $0.50 * * *$ & & & & \\
\hline $\begin{array}{l}\text { Collective } \\
\text { Efficacy } \\
\text { (Knowledge) }\end{array}$ & $0.21 * * *$ & $0.21^{* * *}$ & $0.06^{*}$ & $0.28^{* * *}$ & $0.38^{* * *}$ & $0.44^{* * *}$ & & & \\
\hline Extra courses & $0.36^{* * *}$ & $0.32 * * *$ & $0.12^{* * *}$ & $0.32 * * *$ & $0.21^{* * *}$ & $0.16^{* * *}$ & $0.09 * * *$ & & \\
\hline Age & $0.04^{+}$ & -0.01 & 0.02 & -0.03 & 0.00 & -0.01 & -0.03 & 0.03 & \\
\hline Sex (female) & $0.11^{* * *}$ & $0.15^{* * *}$ & $0.05^{+}$ & $0.13^{* * *}$ & $0.11^{* * *}$ & -0.01 & $0.09^{* * *}$ & $0.08^{* * *}$ & $-0.15^{* * *}$ \\
\hline
\end{tabular}

\section{References}

1. Intergovernmental Panel on Climate Change. Summary for policymakers. In Climate Change 2021: The Physical Science Basis. Contribution of Working Group I to the Sixth Assessment Report of the Intergovernmental Panel on Climate Change; Masson-Delmotte, V., Zhai, P., Pirani, A., Connors, S.L., Péan, C., Berger, S., Caud, N., Chen, Y., Goldfarb, L., Gomis, M.I., et al., Eds.; Cambridge University Press: Cambridge, UK, 2021.

2. Hickman, C.; Marks, E.; Pihkala, P.; Clayton, S.; Lewandowski, R.E.; Mayall, E.E.; Wray, B.; Mellor, C.; van Susteren, L. Climate anxiety in children and young people and their beliefs about government responses to climate change: A global survey. Lancet Planet. Health 2021, 5, e863-e873. [CrossRef]

3. Sciberras, E.; Fernando, J.W. Climate change-related worry among Australian adolescents: An eight-year longitudinal study. Child Adolesc. Ment. Health 2021, 27, 22-29. [CrossRef] [PubMed]

4. Lee, K.; Gjersoe, N.; O’Neill, S.; Barnett, J. Youth perceptions of climate change: A narrative synthesis. Wiley Interdiscip. Rev. Clim. Chang. 2020, 11, e641. [CrossRef]

5. Corner, A.; Roberts, O.; Chiari, S.; Völler, S.; Mayrhuber, E.S.; Mandl, S.; Monson, K. How do young people engage with climate change? The role of knowledge, values, message framing, and trusted communicators. Wiley Interdiscip. Rev. Clim. Chang. 2015, 6, 523-534. [CrossRef]

6. Stern, P.C. New environmental theories: Toward a coherent theory of environmentally significant behavior. J. Soc. Issues 2000, 56, 407-424. [CrossRef]

7. Stern, P.; Dietz, T.; Abel, T.; Guagnano, G.; Kalof, L. A Value-Belief-Norm theory of support for social movements: The case of environmentalism. Hum. Ecol. Rev. 1999, 6, 81-97.

8. Schwartz, S.H. Normative influences on altruism. In Advances in Experimental Social Psychology; Berkowitz, L., Ed.; Academic Press: New York, NY, USA, 1977; Volume 10, pp. 221-279.

9. Schwartz, S.H. Universals in the content and structure of values: Theory and empirical tests in 20 countries. In Advances in Experimental Social Psychology; Zanna, M., Ed.; Academic Press: New York, NY, USA, 1992; Volume 25, pp. 1-65.

10. Dunlap, R.E.; Van Liere, K.D. The "new environmental paradigm". J. Environ. Educ. 1978, 9, 10-19. [CrossRef]

11. Ojala, M. Climate change skepticism among adolescents. J. Youth Stud. 2015, 18, 1135-1153. [CrossRef]

12. Stevenson, K.; Peterson, N. Motivating action through fostering climate change hope and concern and avoiding despair among adolescents. Sustainability 2016, 8, 6. [CrossRef]

13. Amel, E.; Manning, C.; Scott, B.; Koger, S. Beyond the roots of human inaction: Fostering collective effort toward ecosystem conservation. Science 2017, 356, 275-279. [CrossRef]

14. Fritsche, I.; Barth, M.; Jugert, P.; Masson, T.; Reese, G. A social identity model of pro-environmental action (SIMPEA). Psychol. Rev. 2018, 125, 245-269. [CrossRef]

15. Koletsou, A.; Mancy, R. Which efficacy constructs for large-scale social dilemma problems? Individual and collective forms of efficacy and outcome expectancies in the context of climate change mitigation. Risk Manag. 2011, 13, 184-208. [CrossRef]

16. Schwartz, S.H.; Struch, N.; Bilsky, W. Values and social intergroup motives: A study of Israeli and German students. Soc. Psychol. Q. 1990, 53, 185-198. [CrossRef]

17. De Groot, J.I.; Steg, L. Value orientations and environmental beliefs in five countries: Validity of an instrument to measure egoistic, altruistic and biospheric value orientations. J. Cross-Cult. Psychol. 2007, 38, 318-332. [CrossRef] 
18. De Groot, J.I.; Steg, L. Value orientations to explain beliefs related to environmental significant behavior: How to measure egoistic, altruistic, and biospheric value orientations. Environ. Behav. 2008, 40, 330-354. [CrossRef]

19. Schwartz, S.H.; Cieciuch, J.; Vecchione, M.; Davidov, E.; Fischer, R.; Beierlein, C.; Ramos, A.; Verkasalo, M.; Lönnqvist, J.-E.; Demirutku, K.; et al. Refining the theory of basic individual values. J. Personal. Soc. Psychol. 2012, 103, 663-688. [CrossRef]

20. Jansson, J.; Marell, A.; Nordlund, A. Exploring consumer adoption of a high involvement eco-innovation using value-belief-norm theory. J. Consum. Behav. 2011, 10, 51-60. [CrossRef]

21. Lind, H.B.; Nordfjærn, T.; Jørgensen, S.H.; Rundmo, T. The value-belief-norm theory, personal norms and sustainable travel mode choice in urban areas. J. Environ. Psychol. 2015, 44, 119-125. [CrossRef]

22. De Groot, J.I.; Steg, L. Relationships between value orientations, self-determined motivational types and pro-environmental behavioural intentions. J. Environ. Psychol. 2010, 30, 368-378. [CrossRef]

23. Hansla, A.; Gamble, A.; Juliusson, A.; Gärling, T. The relationships between awareness of consequences, environmental concern, and value orientations. J. Environ. Psychol. 2008, 28, 1-9. [CrossRef]

24. Nordlund, A.M.; Garvill, J. Effects of values, problem awareness, and personal norm on willingness to reduce personal car use. J. Environ. Psychol. 2003, 23, 339-347. [CrossRef]

25. Raymond, C.M.; Brown, G.; Robinson, G.M. The influence of place attachment, and moral and normative concerns on the conservation of native vegetation: A test of two behavioural models. J. Environ. Psychol. 2011, 31, 323-335. [CrossRef]

26. Schuster, C.; Pinkowski, L.; Fischer, D. Intra-individual value change in adulthood: A systematic literature review of longitudinal studies assessing Schwartz's value orientations. Z. Psychol. 2019, 227, 42. [CrossRef]

27. Daniel, E.; Benish-Weisman, M. Value development during adolescence: Dimensions of change and stability. J. Personal. 2019, 87, 620-632. [CrossRef] [PubMed]

28. Bardi, A.; Lee, J.A.; Hofmann-Towfigh, N.; Soutar, G. The structure of intraindividual value change. J. Personal. Soc. Psychol. 2009, 97, 913-929. [CrossRef] [PubMed]

29. Hofmann-Towfigh, N. Do students' values change in different types of schools? J. Moral Educ. 2007, 36, 453-473. [CrossRef]

30. Vecchione, M.; Schwartz, S.; Alessandri, G.; Döring, A.K.; Castellani, V.; Caprara, M.G. Stability and change of basic personal values in early adulthood: An 8-year longitudinal study. J. Res. Personal. 2016, 63, 111-122. [CrossRef]

31. Ignell, C.; Davies, P.; Lundholm, C. A longitudinal study of upper secondary school students' values and beliefs regarding policy responses to climate change. Environ. Educ. Res. Online Adv. Publ. 2018, 25, 615-632. [CrossRef]

32. Whitley, C.T.; Takahashi, B.; Zwickle, A.; Besley, J.C.; Lertpratchya, A.P. Sustainability behaviors among college students: An application of the VBN theory. Environ. Educ. Res. 2018, 24, 245-262. [CrossRef]

33. Menzel, S.; Bögeholz, S. Values, beliefs and norms that foster Chilean and German pupils' commitment to protect biodiversity. Int. J. Environ. Sci. Educ. 2010, 5, 31-49.

34. Steg, L.; Dreijerink, L.; Abrahamse, W. Factors influencing the acceptability of energy policies: A test of VBN theory. J. Environ. Psychol. 2005, 25, 415-425. [CrossRef]

35. Kaplan, R.; Kaplan, S. Adolescents and the natural environment: A time out. In Children and Nature: Psychological, Sociocultural, and Evolutionary Investigations; Kahn, P.H., Kellert, S.R., Eds.; The MIT Press: Cambridge, MA, USA, $2002 ;$ pp. $227-257$.

36. Twenge, J.M.; Campbell, W.K.; Freeman, E.C. Generational differences in young adults' life goals, concern for others, and civic orientation, 1966-2009. J. Personal. Soc. Psychol. 2012, 102, 1045-1062. [CrossRef]

37. Guagnano, G.A. Locus of control, altruism and agentic disposition. Popul. Environ. 1995, 17, 63-77. [CrossRef]

38. Ballantyne, R.; Connell, S.; Fien, J. Students as catalysts of environmental change: A framework for researching intergenerational influence through environmental education. Environ. Educ. Res. 1998, 4, 285-298. [CrossRef]

39. Busse, M.; Menzel, S. The role of perceived socio-spatial distance in adolescents' willingness to engage in pro-environmental behavior. J. Environ. Psychol. 2014, 40, 412-420. [CrossRef]

40. Wilks, L.; Harris, N. Examining the conflict and interconnectedness of young people's ideas about environmental issues, responsibility and action. Environ. Educ. Res. 2016, 22, 683-696. [CrossRef]

41. Kloeckner, C.A. A comprehensive model of the psychology of environmental behaviour-A meta-analysis. Glob. Environ. Chang. 2013, 23, 1028-1038. [CrossRef]

42. Kim, S.; Shin, W. Understanding American and Korean students' support for pro-environmental tax policy: The application of the value-belief-norm theory of environmentalism. Environ. Commun. 2017, 11, 311-331. [CrossRef]

43. Sherif, M. In Common Predicament: Social Psychology of Intergroug Conflict and Cooperation; Houghton Mifflin: Boston, MA, USA, 1966.

44. Clayton, S.; Devine-Wright, P.; Stern, P.C.; Whitmarsh, L.; Carrico, A.; Steg, L.; Swim, J.K.; Bonnes, M. Psychological research and global climate change. Nat. Clim. Chang. 2015, 5, 640-646. [CrossRef]

45. Klein, S.A.; Nockur, L.; Reese, G. Prosociality from the perspective of environmental psychology. Curr. Opin. Psychol. 2022, 44, 182-187. [CrossRef]

46. Kline, R.B. Principles and Practices of Structural Equation Modeling, 3rd ed.; Guilford: New York, NY, USA, 2011.

47. Pulfrey, C.; Schwartz, S.H.; Butera, F. The value of values: How values can predict motivation at school and at work. 2022; Manuscript in preparation.

48. Schwartz, S.H. Les valeurs de base de la personne: Théorie, mesures et applications [Basic personal values: Theory, measures and applications]. Rev. Française Sociol. 2006, 47, 129-168. 
49. Schwartz, S.H. Draft Users Manual: Proper Use of the Schwarz Value Survey, version 14 January 2009; Littrell, R.F., Ed.; Centre for Cross Cultural Comparisons: Auckland, New Zealand, 2009.

50. Milfont, T.L.; Duckitt, J. The environmental attitudes inventory: A valid and reliable measure to assess the structure of environmental attitudes. J. Environ. Psychol. 2010, 30, 80-94. [CrossRef]

51. Levenson, H. Activism and powerful others: Distinctions within the concept of internal-external control. J. Personal. Assess. 1974, 38, 377-383. [CrossRef]

52. Judge, T.A.; Erez, A.; Bono, J.E.; Thoresen, C.J. Are measures of self-esteem, neuroticism, locus of control, and generalized self-efficacy indicators of a common core construct? J. Personal. Soc. Psychol. 2002, 83, 693-710. [CrossRef]

53. Chen, M.-F. Self-efficacy or collective efficacy within the cognitive theory of stress model: Which more effectively explains people's self-reported proenvironmental behavior? J. Environ. Psychol. 2015, 42, 66-75. [CrossRef]

54. Jugert, P.; Greenaway, K.H.; Barth, M.; Büchner, R.; Eisentraut, S.; Fritsche, I. Collective efficacy increases pro-environmental intentions through increasing self-efficacy. J. Environ. Psychol. 2016, 48, 12-23. [CrossRef]

55. Muthén, L.K.; Muthén, B.O. (1998-2017). Mplus User's Guide. Available online: https://www.statmodel.com/download/ usersguide/MplusUserGuideVer_8.pdf (accessed on 24 January 2022).

56. Hu, L.; Bentler, P.M. Cutoff criteria for fit indexes in covariance structure analysis: Conventional criteria versus new alternatives. Struct. Equ. Model. 1999, 6, 1-55. [CrossRef]

57. Schermelleh-Engel, K.; Moosbrugger, H.; Müller, H. Evaluating the fit of structural equation models: Tests of significance and descriptive goodness-of-fit measures. Methods Psychol. Res. Online 2003, 8, 23-74.

58. Stern, P.C. Psychology: Fear and hope in climate messages. Nat. Clim. Chang. 2012, 2, 572-573. [CrossRef]

59. Rabinovich, A.; Morton, T.A.; Postmes, T.; Verplanken, B. Think global, act local: The effect of goal and mindset specificity on willingness to donate to an environmental organization. J. Environ. Psychol. 2009, 29, 391-399. [CrossRef]

60. Wong-Parodi, G.; Rubin, N.B. Exploring how climate change subjective attribution, personal experience with extremes, concern, and subjective knowledge relate to pro-environmental attitudes and behavioral intentions in the United States. J. Environ. Psychol. 2022, 79, 101728. [CrossRef]

61. Latkin, C.; Dayton, L.; Coyle, C.; Yi, G.; Winiker, A.; German, D. The association between climate change attitudes and COVID-19 attitudes: The link is more than political ideology. J. Clim. Chang. Health 2022, 5, 100099. [CrossRef]

62. McKinnon, C. Climate change: Against despair. Ethics Environ. 2014, 19, 31-48. [CrossRef]

63. Snyder, C.R.; Harris, C.; Anderson, J.R.; Holleran, S.A.; Irving, L.M.; Sigmon, S.T.; Yoshinobu, L.; Gibb, J.; Langelle, C.; Harney, P. The will and the ways: Development and validation of an individual-differences measure of hope. J. Personal. Soc. Psychol. 1991, 60, 570-585. [CrossRef]

64. Ojala, M. Regulating worry, promoting hope: How do children, adolescents, and young adults cope with climate change? Int. J. Environ. Sci. Educ. 2012, 7, 537-561.

65. Li, C.; Monroe, M.C. Development and validation of the climate change hope scale for high school students. Environ. Behav. 2018, 50, 454-479. [CrossRef]

66. Ojala, M. Coping with climate change among adolescents: Implications for subjective well-being and environmental engagement. Sustainability 2013, 5, 2191-2209. [CrossRef]

67. Bouman, T.; Steg, L.; Dietz, T. Insights from early COVID-19 responses about promoting sustainable action. Nat. Sustain. 2021, 4, 194-200. [CrossRef]

68. Clayton, S.; Kals, E.; Feygina, I. Justice and environmental sustainability. In Handbook of Social Justice Theory and Research; Sabbagh, C., Schmitt, M., Eds.; Springer: New York, NY, USA, 2016; pp. 369-386.

69. Syme, G.J.; Kals, E.; Nancarrow, B.E.; Montada, L. Ecological risks and community perceptions of fairness and justice: A cross-cultural model. Risk Anal. 2000, 20, 905-916. [CrossRef] [PubMed]

70. Reese, G.; Jacob, L. Principles of environmental justice and pro-environmental action: A two-step process model of moral anger and responsibility to act. Environ. Sci. Policy 2015, 55, 88-94. [CrossRef]

71. Syme, G.J.; Nancarrow, B.E.; McCreddin, J.A. Defining the components of fairness in the allocation of water to environmental and human uses. J. Environ. Manag. 1999, 57, 51-70. [CrossRef]

72. Lawson, D.F.; Stevenson, K.T.; Peterson, M.N.; Carrier, S.J.; Strnad, R.L.; Seekamp, E. Children can foster climate change concern among their parents. Nat. Clim. Chang. 2019, 9, 458-462. [CrossRef] 